\title{
Students' Creative Thinking Process based on the Wallas Stage in Solving Mathematical Modeling Problems
}

\author{
Ila Mardianti \\ Mathematics Education Program, Postgraduate \\ Program, Universitas Negeri Surabaya, Ketintang St., \\ Surabaya 60231, Indonesia \\ ilamardianti08@gmail.com
}

\author{
Masriyah, Pradnyo Wijayanti \\ Department of Mathematics Education, Universitas \\ Negeri Surabaya, Ketintang, Surabaya 60231, \\ Indonesia, \\ masriyah@unesa.ac.id,pradnyowijayanti@unesa.ac.id
}

\begin{abstract}
The individual's creative level in solving mathematical problems is of course different. Using mathematics to solve problems is called math applications. The modeling process is very helpful for students in solving mathematical problems related to contextual problems. Four stages of Wallas's creative thinking process are preparation, incubation, illumination, and verification. This study aims to describe the creative thinking process of students based on Wallas stages in solving mathematical modeling problems. Data was collected using tests and interviews. This research was conducted in qualitative descriptive manner. The gathered data analysis were processed through qualitative analysis. Subjects were categorized with high, medium, and low mathematics abilities level. The study involved eight grade students. The results showed that students were categorized to achieve high math ability in which they were capable of solving mathematical problems and were in line with Wallas stages in solving mathematical modeling problems. Students who possessed moderate math skills, they need little time in completing mathematical models and sometimes verification. For those who were categorized to low mathematical abilities, they need longer time to understand the problem and read it over and over. Overall, students make mathematical models according to their understanding that are still incorrect.
\end{abstract}

Keywords-Creative Thinking; Wallas; Solving Mathematical Modeling Problems.

\section{INTRODUCTION}

Creative thinking in mathematics or in other fields is a lifestyle that needs to be developed to uncover the challenges of a future that are higher and able to compete with existing environmental conditions. The development of student creativity will look difficult if students are not accustomed to solve problems, to cultivate and hone students' creativity skills so that students must use challenging problems [1]. Many students still find it difficult to solve challenging problems, because in the process it requires a high process of creative thinking.
Problems are defined by Ozsoy and Ataman [2] that "Problem is a phenomenon requiring an individual to choose a strategy and make a decision for a solution in any encountered situation". Problem solving is the process of applying knowledge that has been obtained previously into new situations that are not yet known [3]. So that a problem for someone is not necessarily a problem for others because every student knows the procedure to solve it. Mathematical problems can only be solved if students have motivation, creative thinking skills, skills and knowledge of the problems given in addition to other aspects. Shadiq [4] explains that mathematical models are mathematical ideas as an embodiment of existing problems. Then modeling is a process to get the mathematical model. The researcher uses the same modeling process as used by Galbraith and Stillman [5], because when compared with other modeling processes, it is assisted by thick arrows to show the transition between stages and alternating arrows that indicate a very important relationship from the previous stage to move to the next stage.

Therefore, it can be concluded that problem solving of mathematical modeling is a series of activities in solving mathematical modeling problems starting from clarifying realworld problems, real problems to mathematical models, mathematical models to mathematical solutions, mathematical solutions to checking solutions, checking solutions to revised models or accepting solutions to problem solving by applying skills, creative thinking, experience, and knowledge that have been obtained before.

Munandar [6] states that finding out the creative thinking process of students can be achieved with the aim of creative process developed by Wallas. It is in line with with Mujib, Hevy, and Sukestiyarno [7] in which creative thinking can be levelled up to position students in particular stage.

To understand the characteristics of creative minded people when faced with new mathematical problems or challenges, a benchmark or indicator is needed in order to 
determine the level of individual creative thinking process. According to Wallas there are four stages in the process of creative thinking [8]. The Wallas model consists of preparation, incubation, illumination, and verification. So the creative thinking process of students based on Wallas stages in solving mathematical modeling problems is students build ideas through four stages of creative thinking which include preparation, incubation, illumination, and verification in solving mathematical modeling problems from a reality-based phenomenon.

Wessel [9] states that, "Students who have creative thinking not only use the mathematical knowledge, but also can use new and unusual strategies to solve their problems". To be able to use a new strategy in solving mathematical problems, it requires a high creative process and students who are accustomed to challenging questions. One of the strategies that can help students in solving math problems is modeling. Modeling process is very helpful for students in solving math problems related to real context. Giving students a practice of math problems related to real contexts, can awaken students' awareness that math is very useful, meaningful and has a high contribution to everyday life.

One of the materials in junior high school that uses mathematical modeling is geometry. It is important for teachers to teach mathematical modeling in problem solving especially in mathematics subjects. English and Lesh [10] assert that "With mathematical modelling on the other hand, the task setter starts with reality and looks to mathematics before finally returning to reality to judge the usefulness and desirability of the mathematical model for description or analysis of a real situation".

\section{METHOD}

This type of research is a descriptive study that aims to describe the creative thinking process of students based on Wallas stages in solving mathematical modeling problems. This study uses a qualitative approach. This research was conducted in junior high school. Students are in the concrete operational stage to the formal stage. It is expected that students can have concrete thinking skills to abstract and be able to think creatively so that students are skilled in synthesizing ideas, generating ideas, and applying ideas to solve a problem. The material used in this study is geometry in two-dimentional figure. The following is a description of the process of selecting research subjects: 1) Determination of the group of students who will be used as research subjects. 2) Providing Mathematical Ability Test to find out the basic abilities of students in solving mathematical problems. 3) Assessing the results of mathematical ability test as well as reviewing the document of the value of mathematics learning outcomes on the previous semester report card so that three categories of students with high, medium and low abilities will be obtained. 4) Make observations and communicate directly with three students who have been selected.
The procedure of this study as follows: 1) the preparation phase which consists of preparing instruments namely Mathematics Ability Test, Mathematical Problem Solving Test, and interview guidelines as well as implementing validation. 2) the data collection stage includes the students' mathematics learning outcomes scores on the previous report card which will then be combined with the Mathematics Ability Test, conducting interviews based on the Mathematical Problem Solving Test 1 and 2 test results using a mobile notebook and audio recorder handphone, so that the interview results can be recorded properly. 3) the data analysis stage is evaluating the Mathematical Problem Solving Test 1 and 2 test results in each mathematical problem solving test and refers to indicators of students' thinking processes based on Wallas stages in solving mathematical modeling problems and evaluating the results of subject interviews. Then do data reduction, data presentation and conclusion drawing. 4) report preparation phase.

\section{RESULTS}

The results of the analysis of mathematical problem solving tests, the creative thinking process of students in solving mathematical modeling problems based on the stages developed by Wallas [8]. Students are given two geometry material questions that use the modeling process in their completion. The results of students' answers were analyzed based on the wallas stages in Table I. The teacher can describe the creative thinking process of students when solving modeling problems with reference to existing indicators. Researchers use the mathematical modeling process according to [5] contained in Table I.

TABLE I. INDICATOR OF STUDENT CREATIVE THINKING PROCESS BASED ON WALLAS STAGES IN SOLVING MATHEMATICAL MODELING PROBLEMS

\begin{tabular}{|c|c|l|}
\hline No. & $\begin{array}{c}\text { Wallas's } \\
\text { Stage }\end{array}$ & \multicolumn{1}{c|}{ Indicator } \\
\hline 1 & Preparation & $\begin{array}{l}\text { Messy real world situation to real world problem } \\
\text { statement } \\
\text { - Clarifying the context of the problem } \\
\text { - Gathering information or mathematical facts } \\
\text { related to the problem } \\
\text { - Identifying ideas / methods that are considered } \\
\text { appropriate } \\
\text { - Establishing ideas / methods that are considered } \\
\text { appropriate real world problem statement to } \\
\text { math model } \\
\text { - Formulating variables to be included in algebraic } \\
\text { models or often called mathematical models }\end{array}$ \\
\hline 2 & Incubation & $\begin{array}{l}\text { - Doing something that has nothing to do with the } \\
\text { problem given } \\
\text { - No longer thinking about problems and } \\
\text { resolving them consciously }\end{array}$ \\
\hline 3 & Illumination & $\begin{array}{l}\text { - Finding key ideas that lead to solving problems } \\
\text { encountered after experiencing the incubation } \\
\text { stage } \\
\text { Building and developing key ideas in solving } \\
\text { problems }\end{array}$ \\
\hline 4. & $\begin{array}{l}\text { Viguring out mathematical model to } \\
\text { mathematical solution } \\
\text { Choosing strategies for presenting mathematical }\end{array}$ \\
\hline
\end{tabular}




TABLE I. CONT.
\begin{tabular}{|c|c|l|}
\hline No. & $\begin{array}{c}\text { Wallas's } \\
\text { Stage }\end{array}$ & \multicolumn{1}{c|}{ Indicator } \\
\hline & & $\begin{array}{l}\text { models } \\
\text { - Applying the right formula } \\
\text { - Performing calculations correctly } \\
\text { - Identifying mathematical solutions with real } \\
\text { problems } \\
\text { - Checking temporary solutions that are } \\
\text { appropriate with the problem } \\
\text { - Revising model or accepting solution } \\
\text { - Verifying the algebraic model/mathematical } \\
\text { model used accordingly or not } \\
\text { - Reviewing the modeling steps again, if the } \\
\text { model is deemed inappropriate }\end{array}$ \\
\hline
\end{tabular}

For students who have high math skills, students can solve problems using the modeling process properly and correctly based on the Wallas stage. Students can properly and quickly understand the problems that exist in the preparation stage and model the problem. At the incubation stage, students only need a few minutes to reflect on the solution to the problem that will be used. After that students look for solutions from mathematical models with appropriate mathematical methods to obtain the correct solution at the illumination stage. Students really take into account the time in doing it and rechecking the solution that was obtained at the verification stage. The following are examples of the results of the work of high-ability math students.

Solution

Given:

- The width of the unchanged garden is $a$

- The area of the unchanged garden is $L_{1}$

- The area of the changed garden is $L_{2}$

The area of both garden is constant, so the equation is $L_{1}=L_{2}$ The area of the garden is as follows.

$$
\begin{gathered}
L_{1}=p_{1} \times l_{1}=(20+a) \times a \\
=\left(20 a+a^{2}\right) \\
\begin{aligned}
L_{2}=p_{2} \times l_{2}=(14+a) \times(a+5) \\
=14 a+70+a^{2}+5 a \\
=a^{2}+14 a+5 a+70 \\
=\left(a^{2}+19 a+70\right) \\
L_{1}=L_{2} \\
20 a+a^{2}=a^{2}+19 a+70 \\
20 a-19 a+a^{2}+\left(-a^{2}\right)=70 \\
a=70
\end{aligned}
\end{gathered}
$$

The value of $a=70$ is substituted to the length of unchanged garden. We get, $20+a=20+70=90$. Hence, $L_{1}=p \times l=90 \times 70=6.300$

After having changes on the garden, we get Width $=a+5=70+5=75$

$$
\begin{aligned}
& \text { Length }=\quad 20-6+a=84, \quad \text { thus } \\
& L_{2}=p \times l=84 \times 75=6.300
\end{aligned}
$$

So, the width of Mr. Anto's garden is 70 meters (The width of unchanged garden) and the length of the garden is $90 \mathrm{~m}$.

The interview result is shown by the following interview excerpts:

Q: Can you explain? What do you understand from the problem so that it can make a settlement like this?

$\mathrm{E}$ : Yes, what I understand here first is that this story is made into a mathematical model to make it easy to do.

Q: The idea from which to conclude that this mathematical model is in accordance with the problem?

E: In this mathematical problem it is said that the length of the field is 20 meters more than the width. That means you can write $a+20$.

For students who have moderate math skills, it takes more time. Students can already understand the problem at the preparation stage and can model problems. At the incubation stage, students do other activities such as playing ballpoint pens and singing for a while. Then at the illumination stage, students' ideas are still not correct so that the mathematical solution needs to be improved at this stage. In order to obtain the expected results.

For students who have low math skills, the creative thinking process is still in the preparation stage.. Students long in understanding the problem and reading it over and over so that they can understand it. In accordance with the understanding gained, students write down their mathematical models. When it is at this incubation stage students tend to invite their friends to talk that does not lead to solving problems. At the illumination stage students have not found an idea of the solution to the problem, so the final stage of verification is not done by students

\section{CONCLUSION}

Creative thinking in mathematics or in any other field is a life skill that needs to be developed to cope with the challenges in the future that are higher and able to compete with existing environmental conditions. In understanding the characteristics of students' creative thinking when solving a new mathematical problem or challenge is not an easy task for a teacher and often less teachers evaluate the student's creative thinking process. Therefore, a benchmark or indicator is needed in order to determine the level of individual creative thinking process. According to Wallas [8] there are four stages in the process of creative thinking. The Wallas model consists of preparation, incubation, illumination, and verification. The researcher uses the same modeling process as used by Galbraith and Stillman [5], because when compared with other modeling processes, the modeling process is assisted by thick arrows to show the transition between stages and alternating arrows that indicate a very important relationship from the previous stage to move to the next stage.

For students in the category of high math skills, students can solve problems properly, correctly and in accordance with 
Wallas stages in solving mathematical modeling problems. Students are accustomed to solving problems carefully and verification first before drawing conclusions. Based on the results of the study, that students with moderate math skills, relatively need a long time to complete mathematical models and sometimes verify. While students with low mathematical abilities, still need guidance from the teacher or friend, how to train students to understand concrete problems into abstract forms (mathematical models) first in order to obtain the correct solution

\section{REFERENCES}

[1] T. Y. E. Siswono, Model Pembelaran Matematika Berbasis Pengajuan dan Pemecahan Masalah untuk Meningkatkan Kemampuan Berpikir Kreatif, Surabaya: Unesa University Press, 2008.

[2] G. Ozsoy and A. Ataman, "The Effect of Metacognitive Strategy Training on Mathematical Problem Solving Achivement", Online Submision, vol. 1, no. 2, pp. 68-83, 2009.

[3] N. Baeti, "Analisis Kemampuan Berpikir Kreatif Siswa dalam Pemecahan Masalah Matematika Di SMP”, Jurnal Pendidikan Matematika STKIP Bima, vol. 6, no. 2, 2015.
[4] F. Shadiq, Strategi Pemodelan dalam Pemecahan Masalah Matematika, Yogyakarta: Graha Ilmu, 2014.

[5] P. Galbraith and G. Stillman, "A Framework for Identifying student Blockages during Transitions in the Modelling Process", ZDMClassifications: C70-M10, vol. 38, No. 2, 2006.

[6] U. Munandar, Pengembangan Kreativitas Anak Berbakat, Jakarta: Rineka Cipta, 2012.

[7] Mujib, R. M. Hevy, dan Y. L. Sukestiyarno, "Evaluasi Proses Berpikir Kreatif berdasarkan Model Wallas bagi Siswa SMP dalam Menyelesaikan Masalah Matematika Al-Jabar", Jurnal Pendidikan Matematika, vol. 8, no. 1, pp. 1-11, 2017.

[8] M. Savic, "Mathematical Problem-Solving via Wallas' Four Stages of Creativity: Implications for the Undergraduate Classroom", The Mathematics Enthusiast, vol. 13, no. 3, Article 6, 2016.

[9] H. Wessels, "Levels of mathematical creativity in model-eliciting activities", Journal of Mathematical Modelling and Application, vol. 1, no. 9, pp. 22-40, 2014.

[10] L. D. English and R. A. Lesh, Ends in View Problems. In R. A. Lesh \& H. M. Doer (Eds.), Beyond constructivism: Models and modelling perspectives on mathematics problem solving, learning, and teaching, Mahwah, NJ: Lawrence Erlbaum, 2003, pp. 297-316. 